\title{
The Effects of the COVID-19 on Our Daily Lives in Bangladesh
}

\author{
Md. Najmus Sayadat Pitol \\ Research Officer \\ Bangladesh Forest Research Institute. \\ Bangladesh. \\ e-mail:najmus.sayadat@gmail.com
}

\author{
Md. Akramul Islam \\ Research Officer \\ Bangladesh Forest Research Institute. \\ Bangladesh. \\ e-mail: akramkukhulna@gmail.com
}

\author{
Shakil Ahmed \\ Student \\ Forestry and Wood Technology Discipline \\ Khulna University, Khulna \\ Bangladesh. \\ e-mail: shakilfwt50@gmail.com
}

\author{
Hready Kumar \\ Student \\ Forestry and Wood Technology Discipline \\ Khulna University, Khulna \\ Bangladesh. \\ e-mail: hreadykumarku@ gmail.com
}

\author{
Tanmoy Dey \\ Research Officer \\ Bangladesh Forest Research Institute. \\ Bangladesh. \\ e-mail: tanmoyfwt100518@gmail.com
}

\author{
Bichitra Kumar Bachar \\ Research Officer \\ Bangladesh Forest Research Institute. \\ Bangladesh. \\ e-mail: bichitra_fwtku@yahoo.com
}

\author{
Rupak Kumar Ghosh \\ Research Officer \\ Bangladesh Forest Research Institute. \\ Bangladesh. \\ e-mail: rupak0617@gmail.com
}

https://doi.org/10.48161/qaj.v2n1a90

\begin{abstract}
The COVID-19 pandemic originated from Wuhan, China, spread around the world with horror and dramatic loss of human life. The economic and social catastrophe has made it even more irresistible. An attempt has been made to find out what kind of psychological and livelihood-related impacts Covid-19 has had on our daily lives. Data had been collected through convenient online surveys where 344 respondents were interviewed. Most of the respondents reported the reduction of movement, income and working hours. The majority reported a noticeable decrease in sleep, health condition and body weight due to the increase of tension where some tensed more. Corona can be avoided by drinking hot water and tea, this idea had increased the amount of hot water and tea consumed by the common people. Many of those who lost their jobs were distressed and others also were distressed at the thought of how long they would stay. The most frightening thing was that the addiction to the virtual world had increased dramatically.
\end{abstract}

Keywords-COVID-19, income, livelihood, lockdown, stress, working hours.

\section{INTRODUCTION}

The COVID-19 pandemic worries us more than any other epidemic in the past, as no other disease has been so widespread in history. The world is under house arrest, and the busy public life has come to a halt suddenly. The COVID-19 originated from Wuhan, China $[1,2]$ and broke out worldwide in December 2019. The World Health Organization (WHO) was obliged to announce a global pandemic on March 11, 2020 [3, 4]. The COVID-19 is highly infectious and is still spreading among people like a chain reaction. So, the WHO advises maintaining social distancing (at least 3 feet) among people and avoids public gatherings to restrain disease transmission [5].

However, different countries around the world have adopted different plans to prevent corona infection like restricting free movement, public gathering, shutting down administrative and educational institutions, closing shops, markets, amusement parks and tourist spots along with the transport system $[6,7,8,9]$. The government of Bangladesh also started strict lockdown from $25^{\text {th }}$ March 2020. The prolonged closing had a significant impact not only on human health but also on our socioeconomic life. People were at risk of losing their income source both in-town and rural areas. Especially the village farmers were incapable of storing their produce due to a lack of cold storage. In town, the people who were utterly dependent on daily labor suffered more for losing their primary income source [10]. The COVID-19 had an upsetting socioeconomic disruption of people and both lives and livelihoods [11]. About $50 \%$ of workers may lose their jobs, whereas 1.6 billion workers are at an instant risk of losing their income globally [12]. 
Global poverty has increased first time since 1990 due to the COVID-19 crisis [13]. Most of the developing countries like Bangladesh declared lockdown forcedly without ensuring the fundamental needs. The public anxiety and disturbance in life increased for weak governance, infrastructure, and health care facilities [14]. The mental health and well-being had severely been affected by sudden physical isolation, fear of losing loved ones, and fear of death from starvation [15, $16,17,18]$. The marginal people like day laborers, transport workers, van and rickshaw-pullers, street vendors and construction workers etc. were the worst sufferers experiencing jobless conditions [18].

Moreover, the longstanding closure of educational institutions hampered students' academic and professional thoughts $[19,20,21]$. Compared to other people, students had experienced many psychological disorders like nervousness, hopelessness, stress, fear, and sleep disturbance in Bangladesh [14, 22, 23]. Most of the people in Bangladesh are poor. They have no other alternative source of income. So, they become worried about that. They don't continue their family correctly. Considering the above statement, the main objective of this study was to find out the phycological and livelihood impact of COVID-19 on Bangladeshi people.

\section{Methodology}

A web-based survey did among Bangladeshi people to investigate the mental health and livelihood impacts of COVID-19. Due to the lockdown, it was impossible to take interviews directly, so we took it online. Using snowball sampling, "Google form" link of the questionnaire distributed among the Bangladeshi people through email, Facebook, WhatsApp, Imo, etc. Our survey purposefully selects educated class of people who have access to the Internet. Basically, this educated class is supposed to be relatively less victimized in Corona. So that we can understand the minimum damage of corona and thus build our own corona resistance. The questionnaire was provided in native Bangla then translated into English. It had three sections, including demographic information, COVID-19 impacts on health and livelihood. The survey was conducted from April $10^{\text {th }}$ to August $28^{\text {th }}, 2021$. A total of 344 respondents of different occupations and residences were responded. All data were analyzed using descriptive (number, percentage, increase, decrease, etc.) statistics through Microsoft Excel 2019.

\section{RESULT}

\section{A. The general condition of the respondents}

One-fourth $(23.5 \%)$ of the respondent were female $(\mathrm{N}=81)$ and nearly two-third $(64.5 \%)$ were lived in town $(\mathrm{N}=222)$ (Table-1). About $67.5 \%(\mathrm{~N}=232)$ were students $(\mathrm{m}=161, \mathrm{f}=71)$ followed by $20.6 \%(\mathrm{~N}=71)$ service-holders $(\mathrm{m}=67 ; \mathrm{f}=4), 8.7 \%(\mathrm{~N}=30)$ unemployment $(\mathrm{m}=24 ; \mathrm{f}=6)$ and $3.2 \%(\mathrm{~N}=11)$ businessmen $(\mathrm{m}=11)$ (Table-1). A total of $59 \%$ of respondents $(\mathrm{N}=203)$ reported that they had medium family with 4-5 members. Most of the respondents (78\%) were not required covid-19 test where only $16 \% \quad(\mathrm{~N}=55)$ affected and only 5 respondents reported that 1 family member was died of covid-19 (Table-1). Within 55 respondents, 30 respondents said that only one member affected in their family followed by 21 reported 2-4 members and only 4 respondents said all the members of their family affected by covid-19 (Table-1). However, only $12.2 \%(\mathrm{~N}=42)$ got covid vaccine and only $2.6 \%(\mathrm{~N}=9)$ got government financial aid. About $80 \%(\mathrm{~N}=275)$ respondents and their family maintained social distance. Within $20 \%$ $(\mathrm{N}=29)$ who were not maintain social distance, most of them lived in village (Table-1). Most of the people were conscious and used masks $(83.2 \%)$ and hand sanitizer and handwash $(79.7 \%)$ where $15 \%$ used masks, hand-sanitizer and handwash before and during covid. Besides, only 34 respondents (mostly marketing officers) attended the office, where 71 were jobholders (Table-1). Moreover, it was found that $47.7 \%(\mathrm{~N}=164)$ respondents passed their majority time using social media. During the lockdown, $14 \%$ of respondents $(\mathrm{N}=49)$ said their family members were married and the ceremony was held at home with relatives (Table-1).

\section{B. Effect on use of social-media}

It was found that most of the respondents $(57 \% ; \mathrm{N}=197)$ used social media in 1-3hours/day before lockdown where only 17 respondents (5\%) used more than 8 hours/day. Unfortunately, 59 of respondents $(17 \%)$ used social media like facebook, viber, imo, online games etc more than 8 hours/day during lockdown. It was also found that $74 \%$ $(\mathrm{N}=256)$ respondents used more time on social media than before. Students were affected more and addicted various types of online games like PUBG, free fire, clash of clans etc during lockdown.

\section{Effect on working hours}

We considered study as working hours for students, households work as working hours for housewives. It was showed that $40 \%(\mathrm{~N}=136)$ respondents worked more than 7 hours/day before lockdown where most of them were housewives and businessmen (Figure-2). But, only 19\% $(\mathrm{N}=64)$ respondents worked more than 7 hours/day during lockdown where most of them were housewives. The women said that even though everyone's working hours were reduced during the lockdown, our increased staying our children and husband were at home most of the time because their schools and offices were closed. Due to which the women were spending more time behind their food and drink. Most of the service-holders performed their official activities from home. During lockdown, some students involved themselves in online marketing especially female.

\section{Effect on income}

Most of the respondents reported the reduction of income even the service holders had received only their salaries but had not received training and travel allowances. The reason for the increase in the number of people with a salary of 110 thousand taka was that many students had earned money by selling various products online during the lockdown (Figure-3). It was seen that the number of people earning above 11 to 60 thousand taka plus had decreased (Figure-3). Because all the businesses, shops, showrooms, offices and courts were closed in the lockdown and the extra income of the people was also stopped. 
Table 1: General Information and Covid-19 status during lockdown

\begin{tabular}{|c|c|c|c|}
\hline Gender & & Residence & \\
\hline Male & $263(76.5 \%)$ & Town & $222(64.5 \%)$ \\
\hline Female & $81(23.5 \%)$ & Village & $122(35.5 \%)$ \\
\hline Occupation & & \multicolumn{2}{|l|}{ Family Member } \\
\hline Students & $232(67.5 \%)$ & Small family (2-3members) & $82(23.8 \%)$ \\
\hline Businessmen & $11(3.2 \%)$ & Medium Family (4-5 members) & $203(59 \%)$ \\
\hline Service-holders & $71(20.6)$ & Large Family (5+ members) & $59(17.2 \%)$ \\
\hline Unemployment & $30(8.7 \%)$ & \multicolumn{2}{|l|}{ Maintained 3 feet distance } \\
\hline \multicolumn{2}{|l|}{ Whether Corona checked } & Yes & $275(79.9 \%)$ \\
\hline No & $268(78 \%)$ & No & $29(20.1 \%)$ \\
\hline Yes, but not affected & $21(6 \%)$ & \multicolumn{2}{|l|}{ Whether vaccinated } \\
\hline Affected & $55(16 \%)$ & Yes & $42(12.2 \%)$ \\
\hline \multicolumn{2}{|l|}{ The death toll in Corona (out of 55) } & No & $302(87.8 \%)$ \\
\hline 1 member & 5 & & \\
\hline No & 50 & \multicolumn{2}{|c|}{ Affected family member number (out of 55) } \\
\hline \multicolumn{2}{|l|}{ Whether got government help } & 1 member & 30 \\
\hline No & $335(97.4 \%)$ & 2 members & 14 \\
\hline Yes & $9(2.6 \%)$ & 3 members & 4 \\
\hline Mask used & & 4 members & 3 \\
\hline Not use before but use now & $286(83.2 \%)$ & All members & 4 \\
\hline Used both time & $52(15.10 \%)$ & \multicolumn{2}{|l|}{ Spent more time on what works } \\
\hline Not used at all & $6(1.7 \%)$ & Social media & $164(47.7 \%)$ \\
\hline \multicolumn{2}{|c|}{ As many family members married in Corona } & Job & $34(9.9 \%)$ \\
\hline 0 & 295 & $\mathrm{Tv}$ & $7(2 \%)$ \\
\hline 1 & 38 & Study & $59(17.2 \%)$ \\
\hline 2 & 4 & Sleep & $36(10.4 \%)$ \\
\hline 3 & 4 & Cooking & $5(1.5 \%)$ \\
\hline $4+$ member & 3 & Others & $39(11.3 \%)$ \\
\hline \multicolumn{4}{|c|}{ Hand Sanitizer and handwash used } \\
\hline Not use before but use now & $274(79.7 \%)$ & & \\
\hline Used both time & $53(15.4 \%)$ & & \\
\hline Not used at all & $17(4.9 \%)$ & & \\
\hline
\end{tabular}
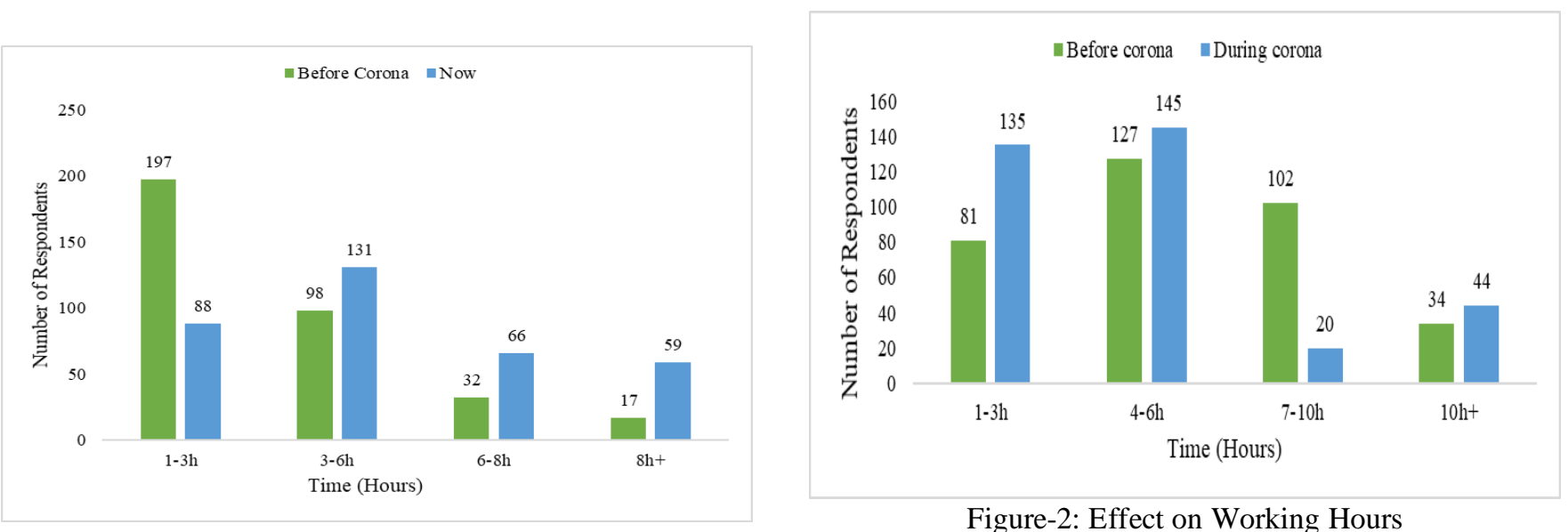

Figure-2: Effect on Working Hours

Figure-1: Effect on use of social-media 


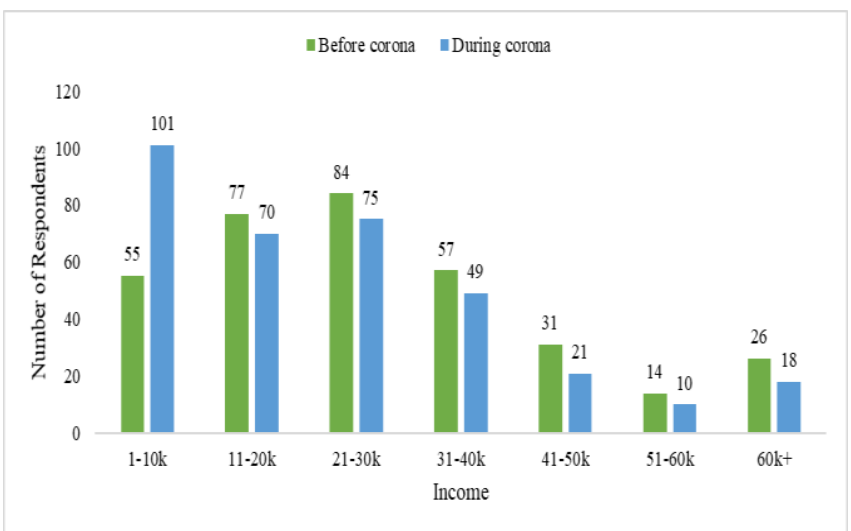

Figure-3: Effect on Income

\section{E. Effect on behavior and health}

Bangladesh government declared a countrywide lockdown from $26^{\text {th }}$ March 2020 to check the community transmission of Covid-19. Since then, the movement of people has decreased a lot. About $90 \%$ of respondents $(\mathrm{N}=310)$ said that their movement decreased where $47.4 \% \quad(\mathrm{~N}=163)$ respondents told the more decrease of movement. Besides, the sleep time $(49.4 \%, \mathrm{~N}=170)$, and body weight increased (36\%, $\mathrm{N}=124)$ due to the staying in the house and the decrease of physical exercise $(45.9 \%, \mathrm{~N}=158)$. Some respondents reported the noticeable decrease of sleep time $(16.3 \%, \mathrm{~N}=56)$, decrease health condition $(68,19.7 \%)$ and body weight loss $(22 \%, \mathrm{~N}=75)$ due to the increase of tension (76.1\%, $\mathrm{N}=262)$ where $27.3 \%(\mathrm{~N}=94)$ respondents tensed more. What to eat, the children's future, when the corona will end, when everything will be normal, etc., are some reasons for increasing anxiety. Among the students who were in fourth-year, masters and looking for a job, they were most worried because all the job tests and recruitment had been stopped in the lockdown.

Corona has brought about a change in our diet. Corona can be avoided by drinking hot water and tea, this idea had increased the amount of hot water and tea consumed $(42.5 \%, \mathrm{~N}=146)$ by the common people. Even those who did not like tea before had made it a habit to drink tea. Those who can afford to increase their immunity have become more accustomed to eating fish and meat (26\%, $\mathrm{N}=88$ ), which has increased the cost of living. The rate of people taking medication has increased $(16.6 \%, \mathrm{~N}=57)$ due to anxiety. Many people were worried about their jobs, especially in the private sector. Many of those who lost their jobs were distressed and others also were distressed at the thought of how long they would stay. Many $(22.7 \%, \mathrm{~N}=78)$ had been forced to change their previous occupations, especially van, rickshaw, auto, bus and truck drivers, because all types of vehicles were closed in lockdown.

Table-2: Effect on food habit, behavior, physical and mental health

\begin{tabular}{|c|c|c|c|}
\hline Movement & Respondents & Sleep & Respondents \\
\hline Decrease & $147(42.7 \%)$ & Increase & $170(49.4 \%)$ \\
\hline Much decrease & $163(47.4 \%)$ & Same & $118(34.3 \%)$ \\
\hline Same & $31(9 \%)$ & Decrease & $56(16.3 \%)$ \\
\hline Increase & $3(0.9 \%)$ & \multicolumn{2}{|c|}{ Physical exercise } \\
\hline Weight & & Increase & $51(14.8 \%)$ \\
\hline Increase & $124(36 \%)$ & Same & $135(39.3 \%)$ \\
\hline Same & $145(42 \%)$ & Decrease & $107(31.1 \%)$ \\
\hline Decrease & $75(22 \%)$ & More Decrease & $51(14.8 \%)$ \\
\hline Tension & & \multicolumn{2}{|c|}{ Hot water uptake } \\
\hline More increase & $94(27.3 \%)$ & Increase & $146(42.5 \%)$ \\
\hline Increase & $168(48.8 \%)$ & Same & $177(51.5 \%)$ \\
\hline Same & $62(18.1 \%)$ & Decrease & $21(6 \%)$ \\
\hline Decrease & $20(5.8 \%)$ & \multicolumn{2}{|c|}{ Health improvement } \\
\hline \multicolumn{2}{|c|}{ Food purchase expenses (meat, fish etc.) } & Increase & $36(10.5 \%)$ \\
\hline Increase & $88(26 \%)$ & Same & $240(69.8 \%)$ \\
\hline Same & $239(69 \%)$ & Decrease & $68(19.7 \%)$ \\
\hline Decrease & $17(5 \%)$ & \multicolumn{2}{|c|}{ Medicine uptake } \\
\hline \multicolumn{2}{|c|}{ Change occupation } & Increase & $57(16.6 \%)$ \\
\hline Yes & $78(22.7 \%)$ & Same & $255(74.1 \%)$ \\
\hline No & $266(77.3 \%)$ & Decrease & $32(9.3 \%)$ \\
\hline
\end{tabular}

\section{DISCUSSION}

The COVID-19 has been spreading globally since December 2019 and increasing fear, anxiety, and mental distress to all [24]. It found that corona affects not only human health but also our social and economic aspects.
Bhuiyan et al. [25] also found similar results. Bangladesh faces much psychological stress and corona also affects livelihood. Paul et al. [10] reported that finding a job was hard for most people in lockdown. About $22.7 \%$ changed their job and some lost their jobs where the working hour decreased rapidly (Figure-2). Statistics showed that more 
than 10 million people would be marginalized due to losing income sources during the lockdown in Bangladesh [26, 27]. About $90 \%$ of respondents said the reduction of income where only some said that they started a business online and sold masks, sanitizer, dresses, cosmetics, etc. Most of the participants in the study were low $(29.4 \%, \mathrm{~N}=101)$ and middle-income $(46.8 \%, \mathrm{~N}=161)$ people with a monthly income of between Tk. 1,000 and Tk. 30,000. It expressed the typical scenario of Bangladeshi people. Similar results were found in other studies [28, 29, 30, 31, 32, 33]. It found that most of the respondents $(59 \%, \mathrm{~N}=203)$ had a medium family with 4-5 members. According to BBS [34], the usual family size of Bangladesh is 4.5 members. Some other studies also found the same result [28, 29, 30, 31, 32, 33].

Corona has taught us to understand the importance of using masks and we are now getting the many benefits of masks. Most of the people were conscious and used masks (83.2\%) and sanitizer and handwash (79.7\%), where $15 \%$ used masks, sanitizer and handwash before (Table-1). About $80 \%$ $(\mathrm{N}=275)$ of respondents and their families maintained social distance. Most of the villagers were not still aware of maintaining the social distance. Moreover, it was found that $47.7 \%(\mathrm{~N}=164)$ of respondents passed their majority time using social media and made us lazy. As a result, working hours had been significantly reduced. Since all the institutions were closed, everyone was spending lazy time sitting at home. As a result, many people had gained weight $(36 \%, \mathrm{n}=124)$ and increased sleep time $(49.4 \%, \mathrm{~N}=170)$ (Table-2). The most frightening thing was that the addiction to the virtual world had increased dramatically. During the lockdown, students were affected more and addicted to various online games like PUBG, free fire, clash of clans, etc. Besides, academic delay [35] and uncertain careers [36] were the leading cause of anxiety among students.

Corona has raised awareness of our diet and helped to identify foods that are more resistant to disease. As a result, trade in fish, meat, eggs and milk has increased. Most of the respondents $(78 \%)$ were not required covid-19 test where only $16 \%(\mathrm{~N}=55)$ were affected and only five respondents reported that one family member died of covid-19 (Table-1).
However, only $12.2 \%(\mathrm{~N}=42)$ got the covid vaccine and only $2.6 \%(\mathrm{~N}=9)$ got government financial aid. Paul et al. (2020) found that only a minor part of the accused received government support. Shammi et al. [18] reported that somehow the government aid does not reach the most vulnerable. Nearly $76 \%$ tensed more, especially the day laborers and the students of Hon's final year, master's and job seekers. No institution was open for the work of the workers. On the other hand, many were nearing the end of their working-age, but all recruitment tests were closed. They were the ones who had lost their way and were not able to decide what to do.

Moreover, prolonged quarantine could result in an emotional disorder of the people [37]. It is widespread for individuals to feel worried, panicked, and devitalized social networks during any epidemic and emergencies [15, 16]. The sudden rise in the number of daily suspects, lack of medical supplies, and media rumors could have worsened the people's anxiety level [38]. Another hand, the people's life was more vulnerable due to inadequate economic backup, limited movement, less space of meeting relatives, friends, and neighbors, lack of help in emergencies, fear of being infected by COVID-19, and lack of backing from the government [10]. It has threatened survival where the majority of the people depend on their daily income in developing countries like Bangladesh. To overcome this crisis government should ensure and promote adequate help, promote e-commerce, and make new policies for mental well-being. Lockdown, isolation, and social distancing is the prerequisite of controlling the coronavirus transmission. Deprived people should be provided with crucial government assistance during a specific period for effective implementation of these measures. Otherwise, this might have a long-term impact on the country. Our study had several limitations that should be cited. Our sample numbers were relatively low. In addition, only those who can use the internet took part in the survey. To get precise results, further studies with more contributors scattered throughout the country and more psychological and livelihood impact variables will be required.

\section{Declaration of interests}

The authors declare no conflict of interest. socioeconomic and psychological miseries on all groups of people worldwide. Corona can create a terrible situation in a populous country like Bangladesh. Mental and physical damage, as well as social and economic life, can be fragile. So, the government, as well as everyone, should be aware to prevent corona. People at all levels of the country need to be vaccinated against coronavirus quickly and everyone needs to be made health conscious. Otherwise, virus transmission will prolong and there is a risk of widespread loss of life due to corona.

\section{Author contributions}

N. S. Pitol, S. Ahmed and H. Kumar conceived, designed the experiments and prepared the questionnaire, N. S. Pitol wrote the first draft, and all authors participated in data collection and helped to prepare final manuscript.

\section{Funding}

This study did not receive any fund.

\section{Acknowledgement}

The authors are grateful to all the respondents who volunteered their time to answer the questions.

\section{REFERENCES}

[1] Harper, C.A., Satchell, L.P., Fido, D., Latzman, R.D., 2020. Functional fear predicts public health compliance in the COVID-19 pandemic. Int. J. Ment. Health Addict. 1-14.

[2] Wu, Y.C., Chen, C.S., Chan, Y.J., 2020. The outbreak of COVID19: an overview. J. Chin. Med. Assoc. 83 (3), 217-220.

[3] World Health Organization., 2020a. Who Director-General's Opening Remarks at the media Briefing on COVID-19 - 11 March 2020. Retrieved 18 April, 2020, from. https://www.who.int/dg/speeches/detail/who-director- 
general-s-opening-remarks-at-the-media-briefing-on-covid19-11-march-2020

[4] Chen, R., Chou, K.R., Huang, Y.J., Wang, T.S., Liu, S.Y., Ho, L.Y., 2006. Effects of a SARS prevention programme in Taiwan on nursing staff's anxiety, depression and sleep quality: a longitudinal survey. Int. J. Nurs. Stud. 43 (2), 215-225.

[5] World Health Organization., 2020b. Coronavirus Disease (Covid19) Advice for the Public. Retrieved 27 June, 2020, from. https://www.who.int/emergencies/diseases/novelcoronavirus-2019/advice-for-public

[6] Ahmed, M.Z., Ahmed, O., Aibao, Z., Hanbin, S., Siyu, L., Ahmad, A., 2020a. Epidemic of covid-19 in China and associated psychological problems. Asian J. Psychiatr. 51, 102092

[7] Anwar, S., Nasrullah, M., Hosen, M.J., 2020. COVID-19 and Bangladesh: challenges and how to address them. Front. Public Health 8 (154)

[8] Chen, L., Yuan, X., 2020. China's ongoing battle against the coronavirus: why did the lockdown strategy work well? Socio-Ecol. Pract. Res. 1-6.

[9] Satici, B., Gocet-Tekin, E., Deniz, M.E., Satici, S.A., 2020 Adaptation of the fear of COVID- 19 scale: its association with psychological distress and life satisfaction in Turkey. Int. J. Ment. Health Addict.

[10] Paul, A., Nath, T.K., Mahanta, J., et al. 2021. Psychological and Livelihood Impacts of COVID-19 on Bangladeshi Lower Income People. Asia Pacific Journal of Public Health. 33(1):100-108. doi:10.1177/1010539520977304

[11] Livelihoods Centre., 2020.COVID-19 and livelihoods. Accessed May 17, 2020. www.livelihoodscenter.org

[12] The Business Standard., 2020. Hunger or coronavirus - who will get us first? Accessed May 17, 2020. https://tbsnews.net/thoughts/hunger-or-coronavirus-whowill-get-us-first-78034

[13] Sumner, A., Hoy, C., Ortiz-Juarez, E., 2020. Estimates of the impact of COVID-19 on global poverty. Accessed May 17,2020. https://www.wider.unu.edu/publication/estimatesimpact-covid-19-global-poverty

[14] Islam, S.D.U., Bodrud-Doza, M., Khan, R.M., Haque, M.A., Mamun, M.A., 2020a. Exploring COVID-19 stress and its factors in Bangladesh: a perception-based study. Heliyon. 6: $\mathrm{e} 04399$

[15] United Nations., 2020. Policy brief: COVID-19 and the need for action on mental health. Accessed May17,2020.https://unsdg.un.org/sites/default/files/202005/UN-Policy-Brief-COVID-19-and mentalhealth.pdf

[16] Inter-Agency Standing Committee., 2020. Interim briefing note: addressing mental health and psychosocial aspects of COVID-19 outbreak. Accessed November 12, 2020.

17] Rajkumar, R.P., 2020. COVID-19 and mental health: a review of the existing literature. Asian J Psychiatry. 52:102066.

18] Shammi, M., Bodrud-Doza, M., Islam, A.R., Rahman, M.M., 2020. COVID-19 pandemic, socioeconomic crisis and human stress in resource-limited settings: a case from Bangladesh. Heliyon. 22: e04063

[19] Patwary, M., Bardhan, M., Disha, A., Kabir, Md., Hossain, Md., Alam, Md., Ashraful H., Billah, S.M., 2020. The Impact of COVID-19 Pandemic on Mental Health of University Student: A Cross-Sectional Study in Bangladesh. SSRN Electronic Journal. 10.2139/ssrn.3682156.

[20] Theoret, C., Ming, X., 2020. Our education, our concerns: the impact on medical student education of COVID-19. Med. Educ. 54 (7), 591-592.

[21] Zhang, Q., He, Y.J., Zhu, Y.H., Dai, M.C., Pan, M.M., Wu, J.Q., $\mathrm{Qu}, \mathrm{F} ., 2020$. The evaluation of online course of traditional Chinese medicine for MBBS international students during the COVID-19 epidemic period. Integrative Med. Res. 9 (3), 100449.

[22] Khan, A.H., Sultana, M.S., Hossain, S., Hasan, M.T., Ahmed, H.U., Sikder, M.T., 2020. The impact of COVID-19 pandemic on mental health \& wellbeing among homequarantined Bangladeshi students: a cross-sectiona pilot study. J. Affect. Disord. 277, 121-128.

[23] Ahmed, O., Ahmed, M.Z., Alim, S.M.A.H.M., Khan, M.D.A.U., Jobe, M.C., 2020b. Covid-19 outbreak in Bangladesh and associated psychological problems: an online survey. Death Stud. $1-10$
[24] Dubey, S., Biswas, P., Ghosh, R., Chatterjee, Subhankar, Dubey, M.J., Chatterjee, Subham, Lahiri, D., Lavie, C.J., 2020. Psychosocial impact of COVID-19. Diabetes Metab. Syndr. Clin. Res. Rev. 14, 779-788. https://doi.org/10.1016/j.dsx.2020.05.035

[25] Bhuiyan, A.I., Sakib, N., Pakpour, A.H., Griffiths, MD., Mamun, M.A., COVID-19-related suicides in Bangladesh due to lockdown and economic factors: case study evidence from media reports. Int J Ment Health Addict. Published May 15, 2020. Accessed May 17, 2020. https://doi.org/10.1007/s11469-020-00307-y

[26] Bodrud-Doza, M., Shammi, M., Bahlman, L., Islam, A.R. Rahman, M., 2020. Psychosocial and socio-economic crisis in Bangladesh due to COVID-19 pandemic: a perceptionbased assessment. Front Public Health. 8:341

[27] Gumber, A., Bulsari, S., COVID-19 impact on Indian economy and health: the emergence of corona-economics. Accessed April 22, 2020. https://mpra.ub.uni-muenchen.de/99659/

[28] A. K. M. Azad., Pitol, M. N. S., A. K., Hara, Y., 2021. Status of Small-scale Rubber and Shifting Cultivators at Bandarbans District, Bangladesh. European Journal of Agriculture and Food Sciences, 3(3), 91-96. https://doi.org/10.24018/eifood.2021.3.3.303

[29] Azad AK, Pitol MNS, Rakkibu MG. 2020. Livelihood status of Sundarbans dependent people at Shymnagar Upazila of Satkhira, Bangladesh. Asian J For 5: 28-35. DOI: 10.13057/asianjfor/r050104

[30] Dey, T., Kamruzzaman, M., Islam, M. A., Bachar, B. K., Pitol, M. N. S., 2020. Attitudes of local people towards community based eco-tourism in the Sundarbans. International Journal of Business, Management and Social Research, $\quad 09(02)$ 528-535. https://doi.org/10.18801/ijbmsr.090220.55

[31] Islam, A., Sharmin, A., Biswas, R., Dey, T., Bachar, B.K., Pitol, M.N.S., 2020. Utilization of Minor Forest Products of the Sundarbans in Bangladesh. Adv in Agri, Horti and Ento: AAHE-126. https://kosmospublishers.com/utilization-ofminor-forest-products-of-the-sundarbans-in-bangladesh/

[32] Nurunnahar., Pitol, M. N. S., Sharmin, A., 2020. Status and Prospects of Agroforestry at Kaligonj Upazila in Satkhira District. European Journal of Agriculture and Food Sciences, 2(6). https://doi.org/10.24018/ejfood.2020.2.6.186

[33] Sheikh, R., Islam, Md., Sharmin, A., Biswas, R., Kumar, J., 2021. Sustainable Agroforestry Practice in Jessore District of Bangladesh. European Journal of Agriculture and Food Sciences. 3. 1-10. DOI:10.24018/ejfood.2021.3.1.150

[34] BBS. 2016. Bangladesh Bureau of Statistics, Statistical Year Book of Bangladesh, Statistics and Informatics Division, Ministry of Planning, Government of the People's Republic of Bangladesh, Dhaka.

[35] Agnew, M., Poole, H., Khan, A., 2019. Fall break fallout: Exploring student perceptions of the impact of an autumn break on stress. Student Success. https://doi.org/10.5204/ssj.v10i3.1412

[36] Sahu, P., 2020. Closure of Universities Due to Coronavirus Disease 2019 (COVID-19): Impact on Education and Mental Health of Students and Academic Staff. Cureus. https://doi.org/10.7759/cureus.7541

[37] Lambert, G.W., Reid, C., Kaye, D.M., Jennings, G.L., Esler, M.D., 2002. Effect of sunlight and season on serotonin turnover in the brain. Lancet. https://doi.org/10.1016/S0140-6736(02)11737-5

[38] Ayittey, F.K., Ayittey, M.K., Chiwero, N.B., Kamasah, J.S., Dzuvor, C., 2020. Economic impacts of Wuhan 2019$\mathrm{nCoV}$ on China and the world. J. Med. Virol. https://doi.org/10.1002/jmv.25706 